\title{
Fentanyl inhibits the progression of gastric cancer through the suppression of MMP-9 via the PI3K/Akt signaling pathway
}

\author{
Chunlai Li, Yi Qin, Yu Zhong, Yinying Qin, Yi Wei, Li Li", Yubo Xie\# \\ Department of Anesthesiology, The First Affiliated Hospital of Guangxi Medical University, Nanning, Guangxi 530021, China \\ Contributions: (I) Conception and design: Y Xie, L Li, C Li ; (II) Administrative support: Y Xie; (III) Provision of study materials or patients: C Li, \\ Y Qin; (IV) Collection and assembly of data: C Li, Y Qin, Y Wei; (V) Data analysis and interpretation: C Li, Y Zhong; (VI) Manuscript writing: All \\ authors; (VII) Final approval of manuscript: All authors. \\ \#These authors contributed equally to this work. \\ Correspondence to: Prof. Yubo Xie; Prof. Li Li. Department of Anesthesiology, The First Affiliated Hospital of Guangxi Medical University, No. 6 \\ Shuang-yong Road, Nanning 530021, China. Email: xybdoctor@163.com; 3196274@qq.com.
}

Background: Fentanyl is a drug commonly used for perioperative and postoperative analgesia. Previous studies have confirmed that fentanyl can affect the progression of gastric cancer; however, this effect has not yet been elucidated. The purpose of our study was thus to investigate the role of fentanyl in gastric cancer and clarify its potential mechanisms.

Methods: A CCK- 8 assay was used to determine the proliferation of MGC-803 cells, while Transwell assay and wound healing assay were used to determine the invasion and migration abilities, respectively. Apoptosis and the cell cycle were assessed by flow cytometry, and the ultrastructure of the cells was examined with a transmission electron microscope. The mRNA expression levels of serine-threonine protein kinase 1 (Akt1), matrix metalloproteinase-9 (MMP-9), and death-associated protein kinase 1 (DAPK1) were evaluated by real-time (RT) quantitative PCR. The protein expression of p-Akt, MMP-9, and caspase-9 was detected by western blot analysis. To study the interaction of fentanyl with the phosphatidylinositol-3-kinase (PI3K)/Akt/ MMP-9 pathway, PI3K inhibitor (LY294002) and MMP-9 inhibitor (SB-3CT) were used to treat the MGC803 cells.

Results: Findings indicated that fentanyl inhibits the proliferation, invasion, and migration of MGC803 cells. Specifically, fentanyl inhibits the expression of MMP-9 and enhances the expression of apoptosispromoting factors such as caspase-9 and DAPK1 through the PI3K/Akt signaling pathway. Cell cycle arrest was observed in the G0/G1 phase. Furthermore, the inhibition of PI3K/Akt/MMP-9 by LY294002 and SB3CT enhanced the anticancer effects of fentanyl.

Conclusions: Fentanyl inhibits the proliferation, invasion and migration of gastric cancer cells by inhibiting the PI3K/Akt/MMP-9 pathway, which could be very useful for gastric cancer treatment.

Keywords: Fentanyl; stomach neoplasm; cell proliferation; apoptosis, matrix metalloproteinase-9 (MMP-9)

Submitted Dec 10, 2019. Accepted for publication Dec 30, 2019.

doi: 10.21037/atm.2019.12.161

View this article at: http://dx.doi.org/10.21037/atm.2019.12.161 


\section{Introduction}

Gastric cancer (GC) has the fourth highest incidence and the second highest mortality among all cancers in the world (1). In 2018, for instance, there were approximately 1,030,000 new cases of GC and 780,000 patients who died from the disease (2). Cancer pain is one of the most common clinical symptoms in the middle and late stages of cancer. It not only damages physical functions but also incurs a serious psychological burden on patients. As a result, the overall health-related quality of life of patients with cancer pain declines. Therefore, within the field of cancer treatment, the alleviation of pain has increasingly become the focus of attention.

Fentanyl, a synthetic opioid receptor agonist, has been widely used in clinical anesthesia, perioperative analgesia, and cancer pain treatment (3). While alleviating cancer pain, it can also affect cancer growth, proliferation, and invasion. Some studies suggest that opioids may play a role in accelerating cancer progression (4-6). However, fentanyl has been reported to inhibit the negative regulation of Ets1 on BRAF-activated lncRNA (BANCR), thus inhibiting the metastasis of colorectal cancer cells (7). Additionally, our previous studies found that $0.0001-1 \mu \mathrm{mol} / \mathrm{L}$ fentanyl could inhibit the growth of GC cells through the regulation of NF- $\kappa B$ and PTEN (8). Taken together, these results demonstrate the anticancer properties of fentanyl. However, the characteristics and mechanisms of fentanyl regulating pathways in GC are still poorly understood.

Cancer invasion and metastasis is a complex and dynamic process regulated by multiple factors. To begin, the phosphatidylinositol-3-kinase (PI3K)/serine-threonine protein kinase (Akt) signaling pathway is involved in the progression of various cancers. It has been shown that activating the PI3K/Akt pathway could prevent cancer cell apoptosis and promote cell cycle progression and tumor angiogenesis, thereby accelerating the adhesion of cancer cells to endothelial cells, ultimately leading to cancer invasion and metastasis $(9,10)$.

In the process of cancer invasion and metastasis, matrix metalloproteinases (MMPs) can mediate the degradation of the extracellular matrix (ECM) and control angiogenesis (11). The expression of p-Akt has been found to be increased after the activation of the PI3K/ Akt pathway, and p-Akt can further activate matrix metalloproteinase-9 (MMP-9), thereby exerting its role in degrading the ECM (12). In the research presented here, the aim was to determine the suppressive effects of fentanyl on GC cell migration and invasion and to explore the related mechanisms.

\section{Methods}

\section{Cell culture}

MGC-803 cells were obtained from the Cell Bank of Chinese Academy of Sciences (Shanghai, China). They were then cultured in Dulbecco's modified Eagle's medium (DMEM) (Invitrogen, Gaithersburg, MD, USA) supplemented with $10 \%$ heat-inactivated fetal bovine serum (FBS) (HyClone, Logan, UT, USA), $75 \mathrm{U} / \mathrm{mL}$ streptomycin, $100 \mathrm{U} / \mathrm{mL}$ penicillin at $37^{\circ} \mathrm{C}$, and $5 \% \mathrm{CO}_{2}$ in a standard humidified incubator. Logarithmic phase MGC803 cells were included for the experiments and randomly divided into 6 groups: group C (a blank control group, cells were not treated with any drugs), group $\mathrm{F}$ (the fentanyltreated group, the final concentration was $0.1 \mu \mathrm{mol} / \mathrm{L}$ ), group LY (the LY294002-treated group, $20 \mathrm{~mol} / \mathrm{L}$ ), group SB (the SB-3CT-treated group, $10 \mu \mathrm{mol} / \mathrm{L}$ ), group FLY (culture medium containing $20 \mu \mathrm{mol} / \mathrm{L}$ LY294002 was added and incubated for $30 \mathrm{~min}$, and then fentanyl was mixed in resulting in a $0.1 \mu \mathrm{mol} / \mathrm{L}$ concentration to be incubated) and group FSB (culture medium containing $10 \mu \mathrm{mol} / \mathrm{L} \mathrm{SB}-3 \mathrm{CT}$ was added first and incubated for $30 \mathrm{~min}$, and then fentanyl was mixed in resulting in a final concentration of $0.1 \mu \mathrm{mol} / \mathrm{L}$ to be incubated).

\section{Cell counting Kit-8 (CCK-8) assay}

MGC-803 cells were placed in plates with 96 wells at a density of $4 \times 10^{3} /$ well. After being incubated for 24,48 and 72 h, $10 \mu \mathrm{L}$ of CCK-8 (Dojindo Laboratories, Kumamoto, Japan) was mixed into the plates, and they were incubated at $37{ }^{\circ} \mathrm{C}$ in a humid environment of $95 \%$ air and $5 \% \mathrm{CO}_{2}$. With a microplate reader (Bio-Rad Laboratories, Inc., Hercules, CA, USA), the absorbance was gauged at $450 \mathrm{~nm}$.

\section{Transwell invasion and wound healing assay}

A Transwell chamber (EMD Millipore, Billerica, MA, USA) having an 8 - $\mu \mathrm{m}$ pore polycarbonate membrane filter, was used for the invasion assay. The filter was inserted into the 24-well chamber and layer of $60 \mu \mathrm{L} /$ well Matrigel was placed above it (BD Biosciences, San Jose, CA, USA). Then, $200 \mu \mathrm{L}$ of serum-free medium of $5 \times 10^{5}$ cells was mixed into the upper chamber, while $10 \%$ FBS and $600 \mu \mathrm{L}$ 
DMEM was mixed into the lower chamber. The chamber was incubated at $37{ }^{\circ} \mathrm{C}$ in a humid environment of $5 \% \mathrm{CO}_{2}$ for $24 \mathrm{~h}$. The Transwell membrane was then fixed with $4 \%$ paraformaldehyde, which was followed by staining with crystal violet for $30 \mathrm{~min}$, and washing three times with phosphate-buffered saline (PBS). A microscope was used to examine those cells that were invading the membrane, with cell invasion being determined using areas photographed at random. MGC-803 cells were cultured in 6-well plates for $24 \mathrm{~h}$. Then, a scratch line was etched on the cells using a $200 \mu \mathrm{L}$ pipette tip, and the plates were subjected to incubation at $37{ }^{\circ} \mathrm{C}$ in $5 \% \mathrm{CO}_{2}$. Wound healing was examined at 0 and $48 \mathrm{~h}$ with an inverted microscope system.

\section{Apoptosis assay}

Trypsin $(0.25 \%)$ was used to harvest cells which were washed two times in ice-cold PBS. Harvested cells were subsequently suspended in $500 \mu \mathrm{L}$ of $1 \times$ binding buffer at a concentration of $5 \times 10^{5}$ cells $/ \mathrm{mL}$. After this, $5 \mu \mathrm{L}$ of annexin $\mathrm{V} /$ fluorescein isothiocyanate (FITC) was mixed into every tube followed first by room-temperature incubation at $4{ }^{\circ} \mathrm{C}$ and then incubation for $10 \mathrm{~min}$ without light. Finally, $10 \mu \mathrm{L}$ of propidium iodide (PI) was mixed into every tube for incubation for another $5 \mathrm{~min}$ at $4{ }^{\circ} \mathrm{C}$ in the dark. Flow cytometry was used to detect the apoptotic cells.

\section{Cell cycle analysis}

The MGC-803 cells treated with $0.25 \%$ trypsin were centrifuged at $1,000 \mathrm{r} / \mathrm{min}$ for $5 \mathrm{~min}$ to separate out the medium. The cells were washed with PBS, the supernatant was disposed of, and the cells were gathered simultaneously. The cells were washed twice with ice-cold PBS and fixed in $80 \%$ ethanol at $4{ }^{\circ} \mathrm{C}$ overnight. After a 3-time wash with PBS, the cells were suspended in $0.1 \mathrm{mg} / \mathrm{mL}$ PI at $37^{\circ} \mathrm{C}$ for half an hour without light. The cell cycle was identified by flow cytometry and expressed as the percentage of cells in each phase of the cell cycle as follows: PI $(\%)=(\mathrm{S}+\mathrm{G} 2 / \mathrm{M}) /$ $(\mathrm{G} 0 / \mathrm{G} 1+\mathrm{S}+\mathrm{G} 2 / \mathrm{M}) \%$. The experiment was performed in triplicate.

\section{Transmission electron microscopy (TEM)}

PBS was used to wash the treated MGC-803 cells which were then fixed in $3 \%$ glutaraldehyde at $4{ }^{\circ} \mathrm{C}$ for $24 \mathrm{~h}$. The experiments were performed with $1 \% \mathrm{OsO}_{4}$ for $1 \mathrm{~h}$, and this was followed by the washing of cells with PBS for $30 \mathrm{~min}$, dehydration in a graded ethanol series, and embedding in Epon. Sections of $50 \mu \mathrm{m}$ were put on copper grids for staining with $2 \%$ uranyl acetate solution and a $1 \%$ solution of lead citrate for $30 \mathrm{~min}$. The ultrastructure was examined with a JEM-1010 transmission electron microscope.

\section{Real-time quantitative polymerase chain reaction (RT- $q P C R)$}

Total RNA was extracted with TRIzol (Invitrogen Life Technologies, Carlsbad, CA, USA), and $2.5 \mu \mathrm{g}$ were reverse transcribed with the Prime Script RT Master Mix Kit (Takara, Tokyo, Japan) as per the manufacturer's instructions. The genes were amplified from cDNA by polymerase chain reaction (PCR) with the following primers: Akt-1 forward 5'-CTTGCTTTCAGGGCTGCTCA-3' and reverse 5'-TACACGTGCTGCCACACGATAC-3'; MMP 9 forward 5'-CAAGCTGGACTCGGTCTTTGA-3' and reverse 5'-GCCTGTGTACACCCACACCT-3'; death-associated protein kinase 1 (DAPK1) forward 5'-ACGTGGTCCGGTATCTCTGTCTG-3 and reverse 5'-TGCTCGTGCTGTTCCGATCTA-3'; and GAPDH forward 5'-GCACCGTCAAGGCTGAGAAC-3' and reverse 5'-TGGTGAAGACGCCAGTGGA-3'. PCR was completed in successive steps as follows: denaturation $(5 \mathrm{~min}$ at $94{ }^{\circ} \mathrm{C}$ ), amplification $\left(95{ }^{\circ} \mathrm{C}\right.$ for $30 \mathrm{~s}, 54-58{ }^{\circ} \mathrm{C}$ for 1 min, and $72{ }^{\circ} \mathrm{C}$ for $1 \mathrm{~min}$ ) and extension $\left(72{ }^{\circ} \mathrm{C}\right.$ for $\left.5 \mathrm{~min}\right)$. Real-time quantitative (RT-q) PCR was conducted with the One Step SYBR ${ }^{\circledR}$ Prime Script ${ }^{\circledR}$ PLUS RT-RNA PCR Kit (TaKaRa Biotechnology, Dalian, China). The Glyceraldehyde 3-phosphate dehydrogenase (GAPDH) mRNA level was used as the internal control, while the relative expression of mRNA was calculated using the $2^{-\Delta \Delta C T}$ method.

\section{Western blotting assay}

The MGC-803 cell proteins were lysed in RIPA buffer containing protease inhibitors (Beyotime Biotechnology, Shanghai, China). Afterwards, protein was extracted, and the protein concentrations were detected using the BCA Protein Assay Kit (Beyotime Biotechnology Co., Ltd., Haimen, China). The proteins (20 $\mu \mathrm{g} / \mathrm{lane})$ were electrophoresed by $12 \%$ SDS-PAGE and electrically placed onto polyvinylidene fluoride (PVDF) membranes (Millipore, USA) in transfer buffer. The membranes were blocked with $5 \%$ bovine serum albumin in Tris-buffered saline/Tween 20 


\section{Page 4 of 10}

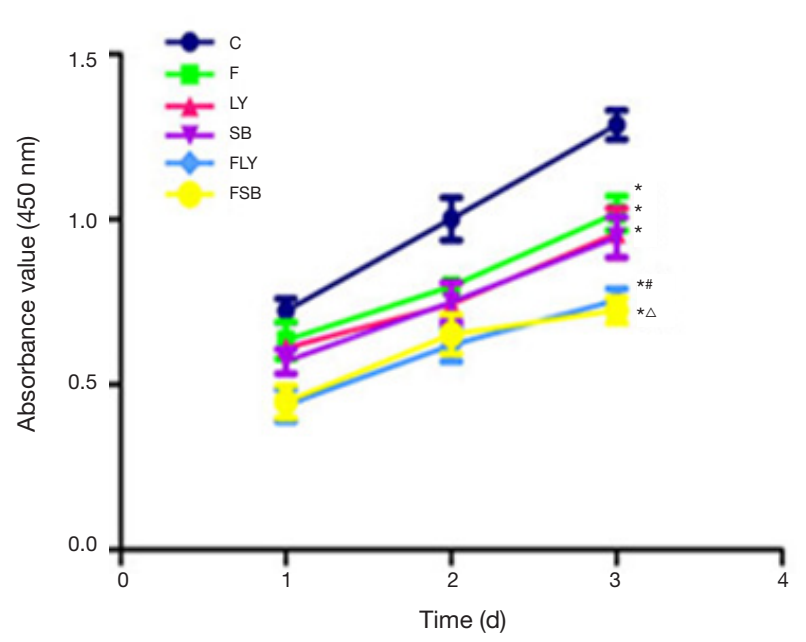

Figure 1 Fentanyl inhibits proliferation of MGC-803 cells. Data are expressed as the mean $\pm \mathrm{SEM}$. *, $\mathrm{P}<0.05$ vs. group $\mathrm{C}$; ${ }^{*}, \mathrm{P}<0.05$ vs. group $\mathrm{F}$ and $\mathrm{LY} ;{ }^{\wedge}, \mathrm{P}<0.05$ vs. group $\mathrm{F}$ and $\mathrm{SB}$.

(TBST) for $2 \mathrm{~h}$ at room temperature and then underwent incubation with the following primary antibodies at $4{ }^{\circ} \mathrm{C}$ overnight: anti-p-AKT (Cell Signaling Technology, Danvers, MA, USA), anti-MMP-9 (ab18785), anticaspase-9 (ab15580), and GAPDH (ab181602). Following this, the membranes were washed three times and incubated for $1.5 \mathrm{~h}$ at room temperature with a horseradish peroxidase (HRP)-conjugated goat anti-rabbit IgG secondary antibody (ab205718, 1:2,000, Abcam). The quantification of immunoreactive intensity was visualized with Image J software (version 2.1.4.7; National Institutes of Health, Bethesda, MD, USA). Subsequent to normalizing with the GAPDH values in the same lane, the relative amounts of protein in each lane were acquired.

\section{Statistical analysis}

Data are presented as the mean \pm SEM and were calculated with Prism (version 6.0; GraphPad Software Inc., San Diego, CA, USA) using one-way analysis of variance (ANOVA) and $t$ test with Dunnett comparison. $\mathrm{P}$ values $<0.05$ indicated a difference of statistical significance.

\section{Results}

\section{Fentanyl inhibits the proliferation of MGC-803 cells}

MGC-803 cell proliferation was detected by the CCK-8 assay, and it was discovered that the MGC-803 cells in the F,

\section{Li et al. Fentanyl inhibits the progression of gastric cancer}

LY, and SB groups showed markedly decreased proliferation compared with that in the control group; in addition, the use of combination drugs caused a greater decrease in proliferation than the use of single drugs $(\mathrm{P}<0.05)$ (Figure 1).

\section{Fentanyl inbibits the invasion and migration of MGC-803 cells}

MGC-803 cell invasion and migration ability were determined by Transwell assay and wound healing assay, respectively. According to the results, the F, LY and SB groups showed a marked reduction in the number of invasive MGC-803 cells and a reduced wound healing rate relative to the control group; also, the use of combination drugs caused a greater decrease than the use of single drugs $(\mathrm{P}<0.05)$ (Figure 2A,B,C,D).

\section{Fentanyl inbibits the progression of the MGC-803 cell cycle}

The cell cycle of MGC-803 cells was determined by flow cytometry. According to the results, compared with the control group, the cell number of the G0/G1 phase in the F, LY, and SB groups was increased, while the cell number of the $S$ phase was significantly decreased $(\mathrm{P}<0.05)$. In addition, in the FLY and FSB groups, the number of cells in the G0/G1 phase showed a greater increased compared with that in the single-drug-treated groups, while the cell number of the $\mathrm{S}$ phase showed a more marked decreased $(\mathrm{P}<0.05)$ (Figure 3A,B).

\section{Fentanyl promotes MGC-803 cell apoptosis}

The apoptosis of MGC-803 cells was detected by flow cytometry. According to the results, the apoptosis rate of the MGC-803 cells in the F, LY and SB groups was clearly reduced in comparison with that in the control group; in addition, the use of combination drugs caused a greater decrease in the apoptosis rate than the use of single drugs $(\mathrm{P}<0.05)$ (Figure 4A,B).

\section{Fentanyl affects the morphological changes of MGC-803 cells}

The changes in the morphology of MGC-803 cells were detected by TEM. According to the results, in the F, LY and SB groups, changes of membrane asymmetry and adhesion, nuclear fragmentation, cell atrophy, and apoptotic 
A
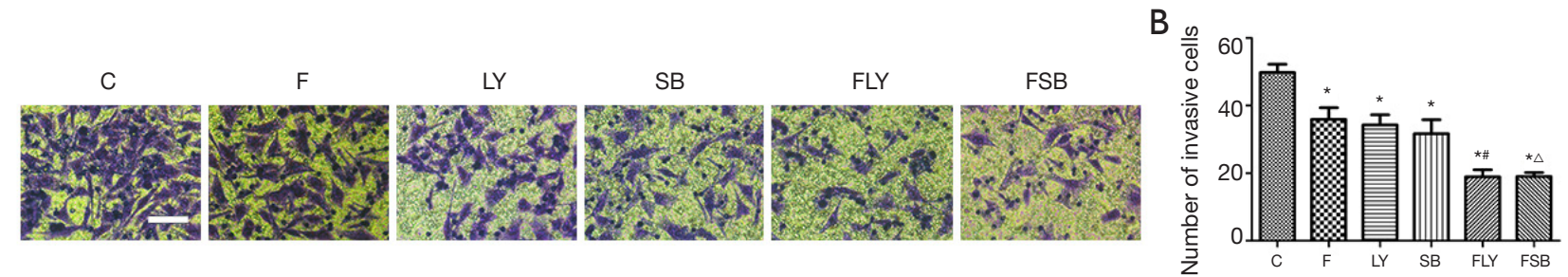

C
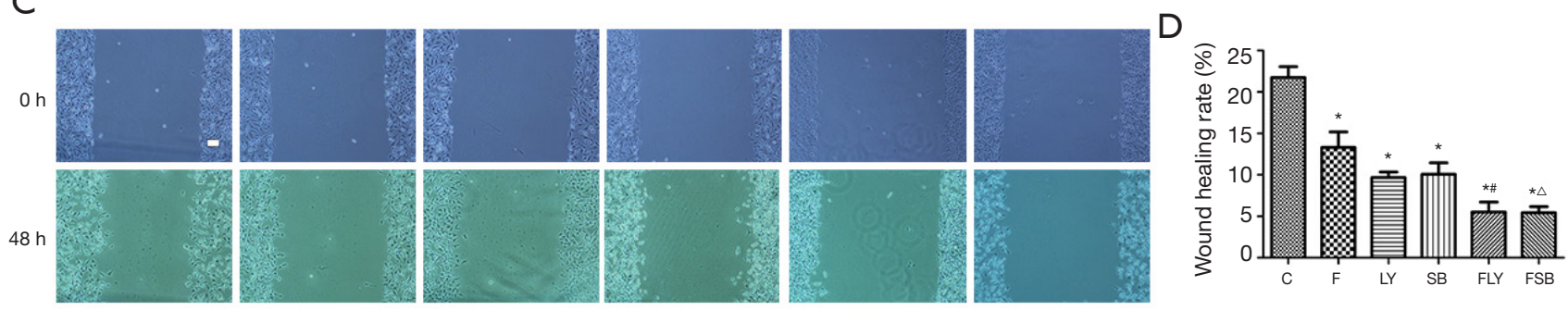

Figure 2 Fentanyl inhibits the invasion and migration of MGC-803 cells. (A,B) MGC-803 cell invasion detection by transwell invasion assay; (C,D) MGC-803 cell migration detection by wound healing assay. Scale bar, $100 \mu \mathrm{m}$. Data are expressed as the mean \pm SEM. *, $\mathrm{P}<0.05$ vs. group $\mathrm{C} ;{ }^{\#}, \mathrm{P}<0.05$ vs. group $\mathrm{F}$ and $\mathrm{LY} ;{ }^{\triangle}, \mathrm{P}<0.05$ vs. group $\mathrm{F}$ and $\mathrm{SB}$.
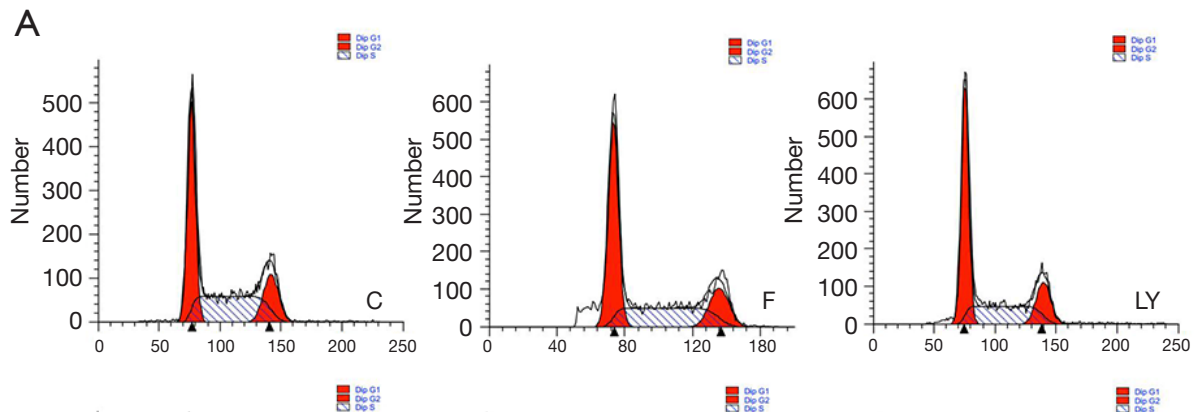

B
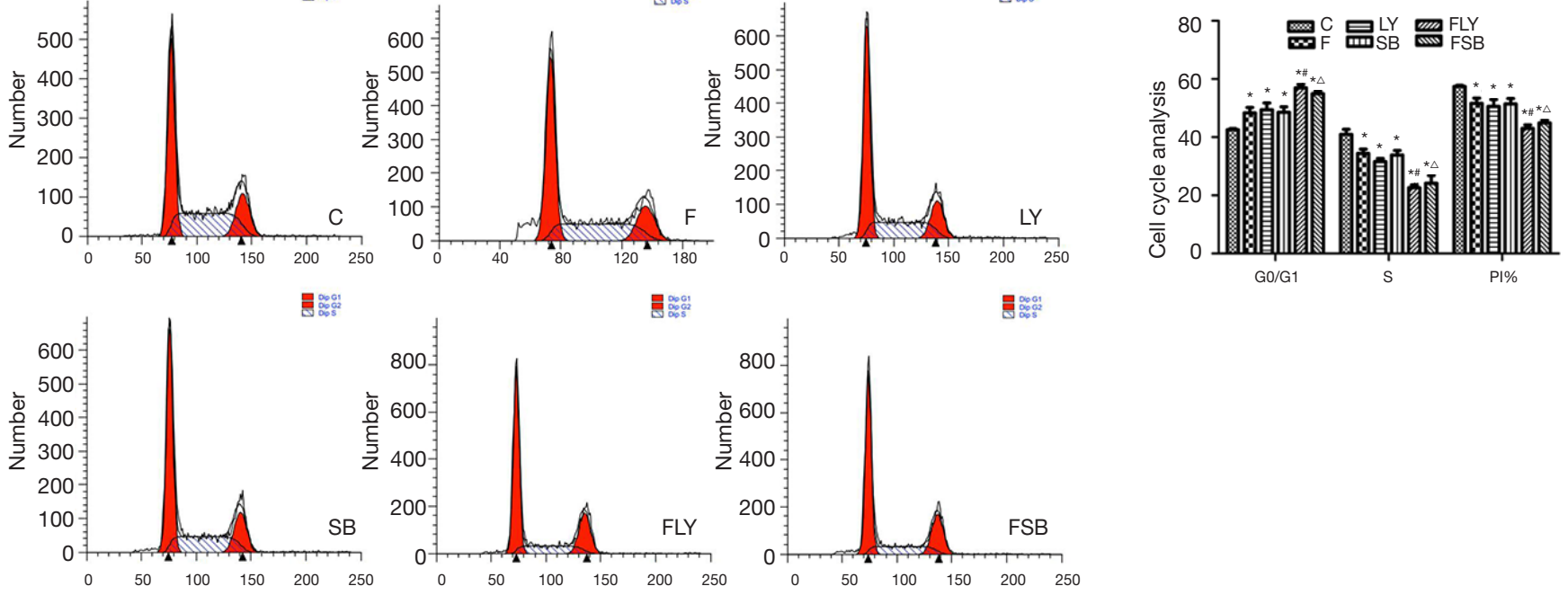

Figure 3 Fentanyl inhibits the progression of cell cycle of MGC-803 cells. (A,B) MGC-803 cells cycle detection by flow cytometry. Data are expressed as the mean $\pm \mathrm{SEM}$. * $\mathrm{P}<0.05$ vs. group $\mathrm{C} ;{ }^{\#}, \mathrm{P}<0.05$ vs. group $\mathrm{F}$ and $\mathrm{LY} ;{ }^{\triangle}, \mathrm{P}<0.05$ vs. group $\mathrm{F}$ and $\mathrm{SB}$. 

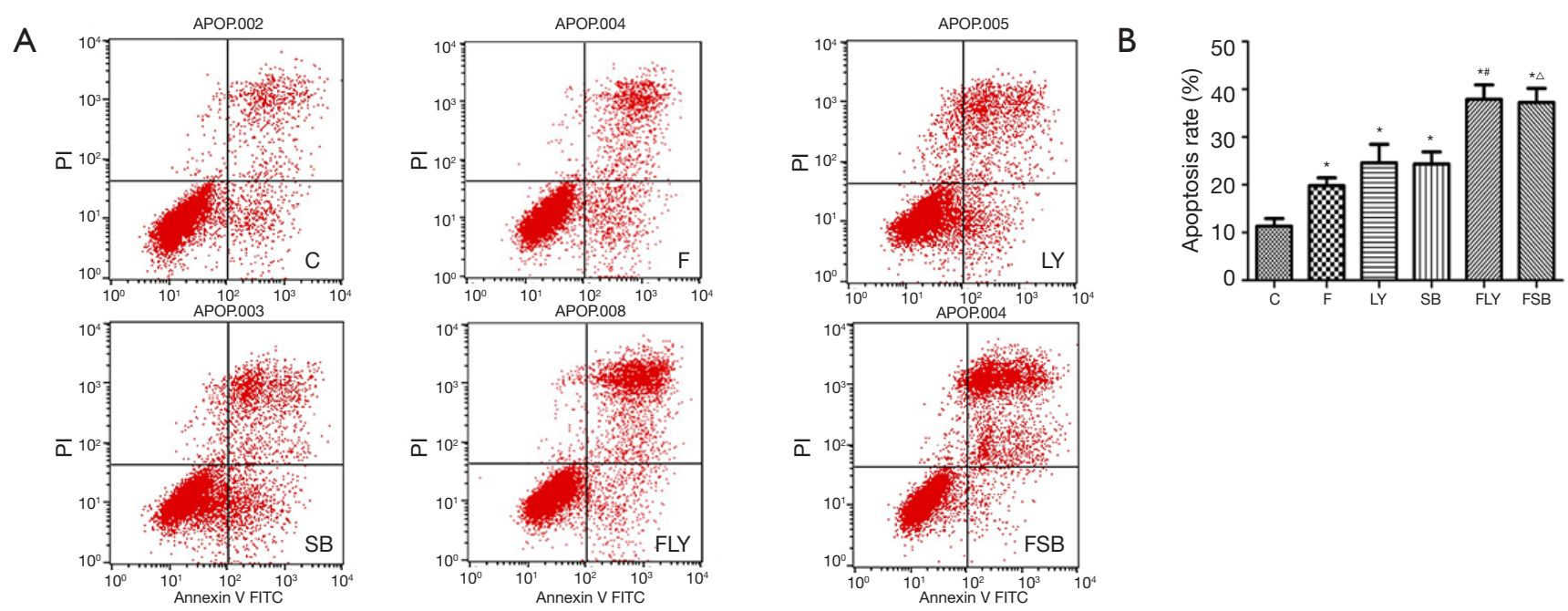

Figure 4 Flow cytometry demonstrates that fentanyl promotes apoptosis of MGC-803 cells. (A) Apoptosis detection images reveal that fentanyl promotes apoptosis of MGC-803 cells; (B) histogram of MGC-803 cell apoptosis indicates that fentanyl promotes apoptosis of MGC-803 cells. Data are expressed as the mean \pm SEM. *, $\mathrm{P}<0.05$ vs. group $\mathrm{C} ;{ }^{*}, \mathrm{P}<0.05$ vs. group $\mathrm{F}$ and $\mathrm{LY} ;{ }^{\wedge}, \mathrm{P}<0.05$ vs. group $\mathrm{F}$ and $\mathrm{SB}$.

bodies, were observed in the cell membranes. In addition, in the cells administered with combination drugs, these morphological changes were more obvious than those in the cells administered with single drugs (Figure 5).

\section{Fentanyl decreases Akt-1 and MMP-9 expression and increases DAPK1 expression}

The related mRNA levels of the MGC-803 cells were detected by RT-qPCR. According to the results, the MGC803 cells in the F, LY and SB groups showed a greater decrease in the expression levels of Akt-1 and MMP9 and a greater increase of DAPK1 expression than the corresponding levels in the control group. In addition, the expression levels of Akt-1 and MMP-9 in the cells administered with combination drugs were more decreased compared with those in the cells administered with single drugs, and the expression of DAPK1 was also increased (Figure 6).

\section{Fentanyl decreases $p$-Akt and MMP-9 expression and increases caspase-9 expression}

The related protein changes of MGC-803 cells were detected by a western blot assay. According to the results, relative to the control group, the MGC-803 cells in the F, LY and SB groups showed a marked decrease in the expression of p-Akt and MMP-9, while the expression of caspase-9 showed a relatively greater increase. In addition, the p-Akt and MMP-9 expression levels of cells administered with combination drugs showed a greater decrease than those in the cells administered with single drugs, while the expression of caspase- 9 was also increased. The data thus suggest that fentanyl can promote the apoptosis of MGC-803 cells $(\mathrm{P}<0.05)$ (Figure $7 A, B)$.

\section{Discussion}

Cancer pain causes grievous suffering to those patients afflicted by it, not only leading to a decline in the quality of life but also negatively influencing their prognosis (13). The WHO's three-step treatment program for cancer pain is still the standard treatment for cancer patients, and this program has achieved great success in the treatment of cancer pain worldwide (14). Many studies have found that opioids can inhibit tumor growth, proliferation, invasion and metastasis when used in cancer pain treatment $(15,16)$. Fentanyl, a representative of the more potent opioids, can affect cancer progression. Our previous study showed that fentanyl could inhibit the progression of human GC MGC803 cells by regulating NF-кB in vivo and in vitro $(8,17)$. However, the mechanism by which fentanyl regulates human GC progression has still not been fully elucidated. In the present study, we detected MGC-803 cells and showed that fentanyl significantly suppressed cell viability, migration, and invasion and promoted the apoptosis that 

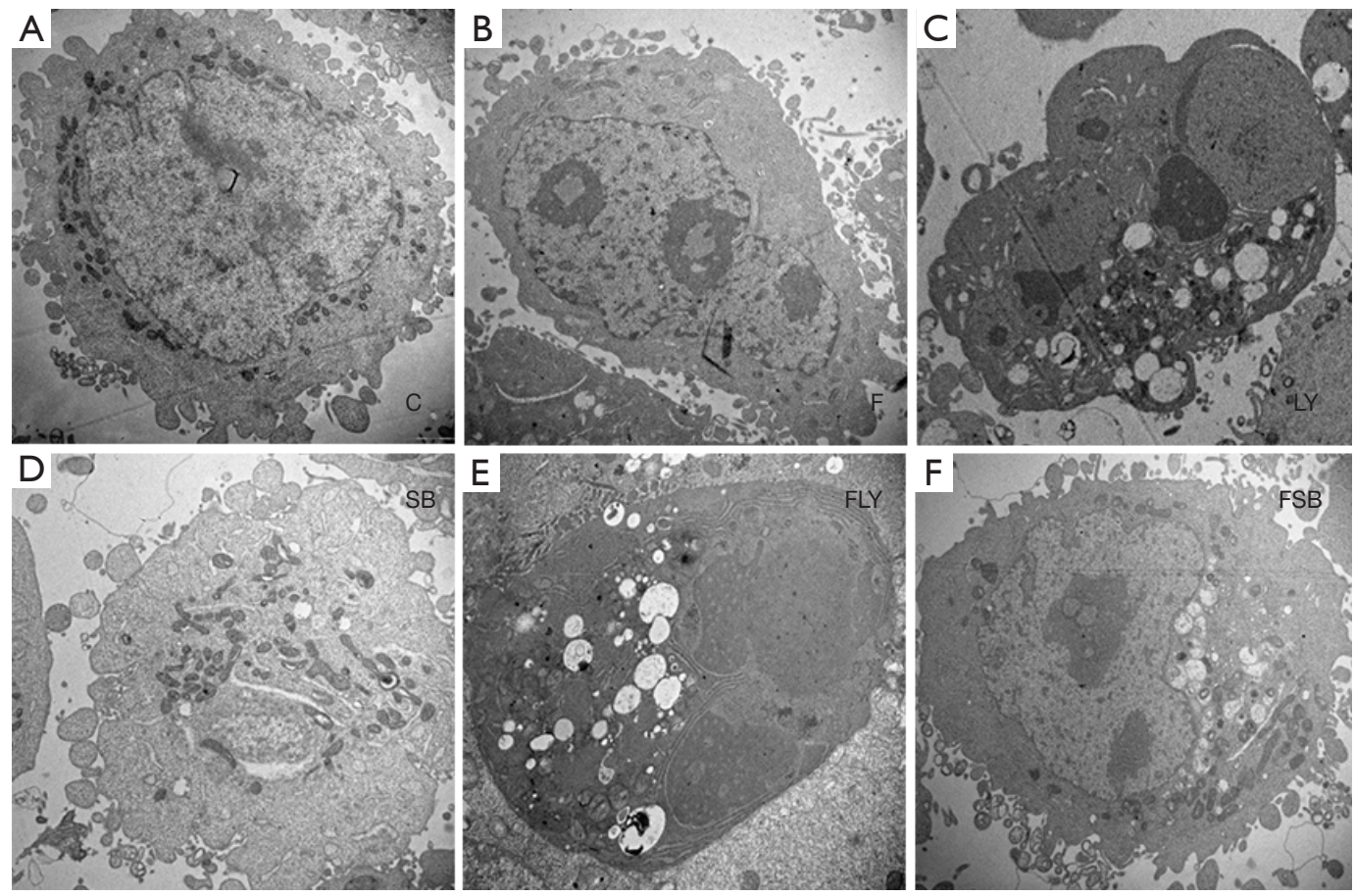

Figure 5 Morphological changes of MGC-803 cells was detected by transmission electron microscopy (TEM).

A

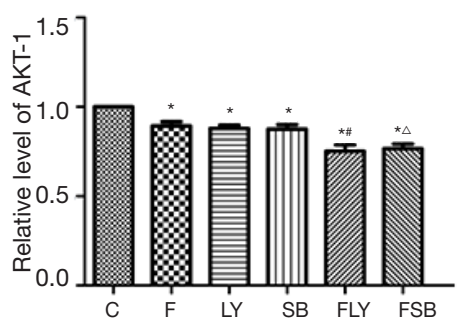

B

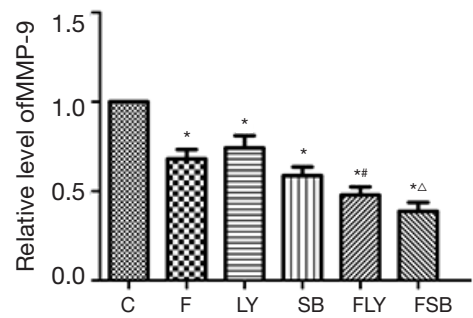

C

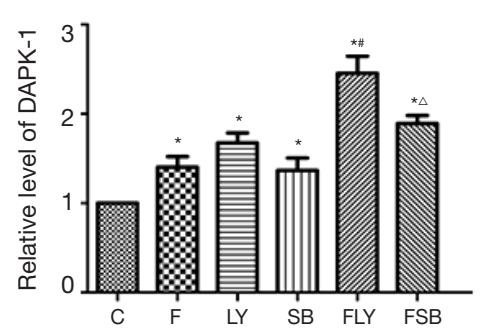

Figure 6 Fentanyl decreases expression level of serine-threonine protein kinase 1 (Akt-1) and matrix metalloproteinase-9 (MMP-9) and increases expression of death-associated protein kinase 1 (DAPK-1). Data are expressed as the mean $\pm \mathrm{SEM}$. * $\mathrm{P}<0.05$ vs. group $\mathrm{C}$; ${ }^{*}, \mathrm{P}<0.05$ vs. group $\mathrm{F}$ and $\mathrm{LY} ;{ }^{\triangle}, \mathrm{P}<0.05$ vs. group $\mathrm{F}$ and $\mathrm{SB}$.

resulted from cell cycle arrest during the G0/G1 phase.

Of the human digestive system cancers, GC has one of the highest incidences. It is acknowledged that the PI3K/Akt signaling pathway figures prominently in the angiogenesis, growth, proliferation, metabolism, angiogenesis, cell cycle, and apoptosis of tumor cells $(18,19)$. Many studies have confirmed that PI3K/Akt signaling has strong associations with the occurrence and development of cancer (20-22). In our study, we demonstrated that p-Akt was activated in GC cells, which could be caused by fentanyl inhibiting the progression of GC.
LY294002 is the first artificially synthesized PI3K inhibitor that specifically blocks the PI3K/Akt signaling pathway and inhibits Akt phosphorylation. The present study demonstrated the suppression of the PI3K/Akt signaling pathway by LY294002 which also increased the anticancer effects of fentanyl in MGC-803 cells.

Cell migration and invasion is a complex process involving the proteolytic degradation of the ECM. MMPs, such as MMP-9, have been shown to degrade the ECM and basement membrane to facilitate cancer cell metastasis and angiogenesis (23). In malignant tumors, 


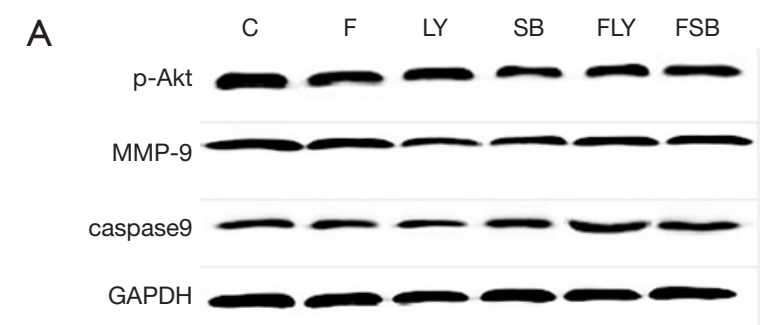

B

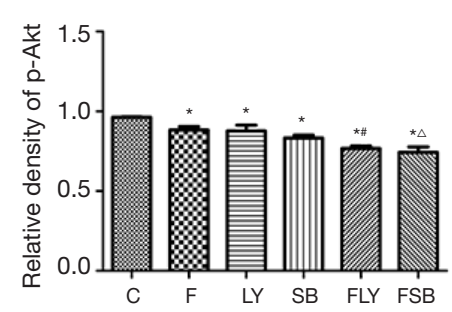

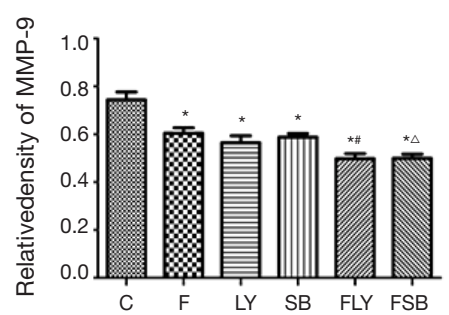

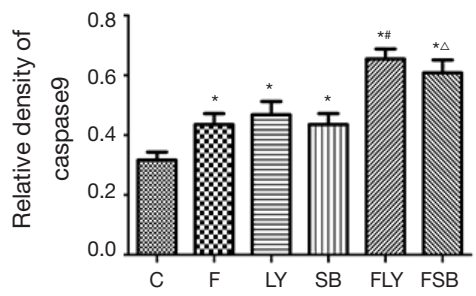

Figure 7 Fentanyl decreases expression of p-Akt and matrix metalloproteinase-9 (MMP-9) and increases expression of caspase. (A,B) Expression of p-Akt, MMP-9 and caspase 9 detection by western blot. Data are expressed as the mean $\pm \mathrm{SEM}$. *, $\mathrm{P}<0.05$ vs. group C; *, $\mathrm{P}<0.05$ vs. group $\mathrm{F}$ and $\mathrm{LY} ;{ }^{\Delta}, \mathrm{P}<0.05$ vs. group $\mathrm{F}$ and $\mathrm{SB}$.

MMPs are mainly secreted by mesenchymal cells in the form of inactive zymogen. Activated MMPs can directly or indirectly participate in a variety of physiological and pathological processes by influencing intracellular signals to mediate cell-to-host ECM degradation, controlling tumor angiogenesis, determining cell adhesion and movement, and regulating tumor cell growth (24). MMP-9 has been established to be associated with the metastasis and the progression of GC (25). Therefore, the expression of phosphorylated Akt (p-Akt) is increased after the activation of the PI3K/Akt pathway; p-Akt can further activate MMP-9, thereby exerting its role in the degradation of the ECM (26). Chang et al. reported a high expression of MMP-9 to be strongly associated with the metastasis and invasion of GC (27). Caspase-9 belongs to the caspase family of proteases, whose activity is important in executing chemotherapy-induced apoptosis $(28,29)$. In addition, DAPK1, a calmodulin-regulated serine/threonine kinase, is a proven tumor suppressor gene and is a critical component of the apoptosis process (30). It is present in many apoptotic lines and causes tumor suppression. Cell proliferation and apoptosis promotion are closely related to tumorigenesis, development, and metastasis (31). MMP-9, caspase-9, and DAPK1 are major downstream molecules of the PI3K/ Akt pathway. SB-3CT is an MMP-9-specific inhibitor that blocks the expression of MMP-9. In the present study, the cells were first incubated with SB-3CT to inhibit the activity of MMP-9, and then fentanyl was added and incubated. The results showed that MMP-9 expression was decreased, and the expressions of caspase-9 and DAPK1 were increased, suggesting that fentanyl may upregulate the downstream apoptosis-related factors, caspase-9 and DAPK1, by inhibiting the activity of MMP-9 downstream of the PI3K/Akt pathway. Therefore, SB-3CT may be able to enhance the inhibitory effects of fentanyl on GC cell growth, invasion, and metastasis.

\section{Conclusions}

Taken together, our findings support the essential role of fentanyl in the progression of GC. The mechanism of fentanyl inhibition on MGC-803 cell growth, invasion, and migration may be via the inhibition of MMP-9 expression and enhancing the expression of apoptosis-promoting factors such as caspase-9 and DAPK1 through the PI3K/ Akt signaling pathway. These results implicate fentanyl as a possible anti-invasion and antimetastatic agent for the treatment of GC cells.

\section{Acknowledgments}

Funding: This work was supported by the Natural Science 
Foundation of China (No. 81560500 and 81160289).

\section{Footnote}

Conflicts of Interest: The authors have no conflicts of interest to declare.

Ethical Statement: The authors are accountable for all aspects of the work in ensuring that questions related to the accuracy or integrity of any part of the work are appropriately investigated and resolved.

\section{References}

1. Torre LA, Bray F, Siegel RL, et al. Global cancer statistics, 2012. CA Cancer J Clin 2015;65:87-108.

2. Yang $\mathrm{Y}$, Xing $\mathrm{P}, \mathrm{Zhou} \mathrm{N}$, et al. The necessity of adjuvant radiotherapy for locally advanced gastric cancer in China. Transl Cancer Res 2019;8:676-82.

3. Qin Z, Wu J, Xu C, et al. Long-term effects of acupuncture for chronic prostatitis/chronic pelvic pain syndrome: systematic review and single-arm meta-analyses. Ann Transl Med 2019;7:113.

4. Lennon FE, Mirzapoiazova T, Mambetsariev B, et al. The Mu opioid receptor promotes opioid and growth factor-induced proliferation, migration and Epithelial Mesenchymal Transition (EMT) in human lung cancer. PLoS One 2014;9:e91577.

5. Chen Y, Qin Y, Li L, et al. Morphine can inhibit the growth of breast cancer MCF-7 cells by arresting the cell cycle and inducing apoptosis. Biol Pharm Bull 2017;40:1686-92.

6. Yang HF, Yu M, Jin HD, et al. Fentanyl promotes breast cancer cell stemness and Epithelial-Mesenchymal Transition by upregulating $\alpha 1$, 6-Fucosylation via Wnt/ $\beta$-Catenin signaling pathway. Front Physiol 2017;8:510.

7. Li AX, Xin WQ, Ma CG. Fentanyl inhibits the invasion and migration of colorectal cancer cells via inhibiting the negative regulation of Ets-1 on BANCR. Biochem Biophys Res Commun 2015;465:594-600.

8. Qin Y, Li L, Chen J, et al. Fentanyl inhibits progression of human gastric cancer MGC-803 cells by NF-kappaB downregulation and PTEN upregulation in vitro. Oncol Res 2012;20:61-9.

9. Shu YJ, Weng H, Ye YY, et al. SPOCK1 as a potential cancer prognostic marker promotes the proliferation and metastasis of gallbladder cancer cells by activating the PI3K/AKT pathway. Mol Cancer 2015;14:12.
10. Wang N, Li Y, Wei J, et al. TBX1 functions as a tumor suppressor in thyroid cancer through inhibiting the activities of the PI3K/AKT and MAPK/ERK Pathways. Thyroid 2019;29:378-94.

11. Che YL, Luo SJ, Li G, et al. The C3G/Rap1 pathway promotes secretion of MMP-2 and MMP-9 and is involved in serous ovarian cancer metastasis. Cancer Lett 2015;359:241-9.

12. Yang L, Shu T, Liang Y, et al. GDC-0152 attenuates the malignant progression of osteosarcoma promoted by ANGPTL2 via PI3K/AKT but not p38MAPK signaling pathway. Int J Oncol 2015;46:1651-8.

13. Bennett MI. Mechanism-based cancer-pain therapy. Pain 2017;158 Suppl 1:S74-8.

14. Mercadante S, Adile C, Masedu F, et al. Factors influencing the use of opioids for breakthrough cancer pain: A secondary analysis of the IOPS-MS study. Eur J Pain 2019;23:719-26

15. Sasamura T, Nakamura S, Iida $Y$, et al. Morphine analgesia suppresses tumor growth and metastasis in a mouse model of cancer pain produced by orthotopic tumor inoculation. Eur J Pharmacol 2002;441:185-91.

16. Koodie L, Yuan H, Pumper JA, et al. Morphine inhibits migration of tumor-infiltrating leukocytes and suppresses angiogenesis associated with tumor growth in mice. Am J Pathol 2014;184:1073-84.

17. He G, Li LI, Guan E, et al. Fentanyl inhibits the progression of human gastric carcinoma MGC-803 cells by modulating NF-kB-dependent gene expression in vivo. Oncol Lett 2016;12:563-71.

18. Zhang Y, Kwok-Shing Ng P, Kucherlapati M, et al. A pancancer proteogenomic atlas of $\mathrm{pi} 3 \mathrm{k} / \mathrm{akt} / \mathrm{m}$ tor pathway alterations. Cancer Cell 2017;31:820-32.e3.

19. Wang H, Zhao Y, Cao L, et al. Metastasis suppressor protein 1 regulated by PTEN suppresses invasion, migration, and EMT of gastric carcinoma by inactivating PI3K/AKT signaling. J Cell Biochem 2019;120:3447-54.

20. Yang SX, Polley E, Lipkowitz S. New insights on PI3K/ AKT pathway alterations and clinical outcomes in breast cancer. Cancer Treat Rev 2016;45:87-96.

21. Zhao H, Xu J, Wang Y, et al. Knockdown of CEACAM19 suppresses human gastric cancer through inhibition of PI3K/Akt and NF-kB. Surg Oncol 2018;27:495-502.

22. Lin $\mathrm{W}, \mathrm{Xie} \mathrm{J}, \mathrm{Xu} \mathrm{N}$, et al. Glaucocalyxin A induces G2/ $M$ cell cycle arrest and apoptosis through the PI3K/Akt pathway in human bladder cancer cells. Int J Biol Sci 2018;14:418-26.

23. Sun Y, Wang X, Zhou Q, et al. Inhibitory effect of emodin 


\section{Page 10 of 10}

on migration, invasion and metastasis of human breast cancer MDA-MB-231 cells in vitro and in vivo. Oncol Rep 2015;33:338-46.

24. Che YL, Luo SJ, Li G, et al. The C3G/Rap1 pathway promotes secretion of MMP-2 and MMP-9 and is involved in serous ovarian cancer metastasis. Cancer Lett 2015;359:241-9.

25. Oku T, Shimada K, Kenmotsu H, et al. Stimulation of peritoneal mesothelial cells to secrete Matrix Metalloproteinase-9 (MMP-9) by TNF- $\alpha$ : A role in the invasion of gastric carcinoma cells. Int J Mol Sci 2018. doi: 10.3390/ijms19123961.

26. Yang L, Shu T, Liang Y, et al. GDC-0152 attenuates the malignant progression of osteosarcoma promoted by ANGPTL2 via PI3K/AKT but not p38MAPK signaling pathway. Int J Oncol 2015;46:1651-8.

27. Chang X, Xu X, Xue X, et al. NDRG1 Controls Gastric Cancer Migration and Invasion through Regulating MMP-

Cite this article as: Li C, Qin Y, Zhong Y, Qin Y, Wei Y, Li L, Xie Y. Fentanyl inhibits the progression of gastric cancer through the suppression of MMP-9 via the PI3K/Akt signaling pathway. Ann Transl Med 2020;8(4):118. doi: 10.21037/ atm.2019.12.161

\section{Li et al. Fentanyl inhibits the progression of gastric cancer}

9. Pathol Oncol Res 2016;22:789-96.

28. Liamarkopoulos E, Gazouli M, Aravantinos G, et al. Caspase 8 and caspase 9 gene polymorphisms and susceptibility to gastric cancer. Gastric Cancer 2011;14:317-21.

29. Zhou D, Zhou Y, Li C, et al. Silencing of B7-H4 suppresses the tumorigenicity of the MGC-803 human gastric cancer cell line and promotes cell apoptosis via the mitochondrial signaling pathway. Int J Oncol 2018;52:1267-76.

30. Singh P, Ravanan P, Talwar P. Death Associated Protein Kinase 1 (DAPK1): A regulator of apoptosis and autophagy. Front Mol Neurosci 2016;9:46.

31. Huang Y, Lin M, Chen X, et al. Evaluation of the prognostic and physiological functions of death associated protein kinase 1 in breast cancer. Oncol Lett 2018;15:8261-8. 